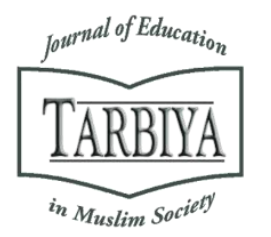

Available online at TARBIYA: Journal of Education in Muslim Society Website:

http://journal.uinjkt.ac.id/index.php/tarbiya

TARBIYA: Journal of Education in Muslim Society, 2 (1), 2015, 47-60

\title{
CONSTRUCTION OF DUAL CURRICULUM IN INDONESIAN EDUCATION SYSTEM DURING THE NEW ORDER GOVERNMENT
}

\author{
Muhammad Zuhdi \\ Syarif Hidayatullah State Islamic University of Jakarta, Indonesia \\ E-mail: zuhdi@uinjkt.ac.id
}

Received: $15^{\text {th }}$ January 2015; Revised: $10^{\text {th }}$ March 2015; Accepted: $15^{\text {th }}$ March 2015

\section{Abstract}

Indonesian education system, beside the fact that it has a single system with a single educational law, accommodates two different official curricula administered by two different ministries, i.e. The Ministry of Education and The Ministry of Religious Affairs. This kind of dual system was officially initiated by the New Order Government in 1970s. Using the social constructionism as a perspective, this study tries to reconstruct the debates on educational policies during the New Order Era. While the Era has passed, the policy of having dual system remains relevant.The study is conducted using a qualitative-historical method, meaning that data are gathered from various resources using the qualitative approach combined with the historical perspective. Data are collected from various written documents as well as interviews with some resource persons. General conclusion of the paper is that the dual curriculum system has existed before the New Order government took the power. The different is that the New Order Government made the dual system official, while the previous system did not recognize religious school as parts of formal education system.

Keywords: dual curricula; Islamic education

\section{Abstrak}

Meskipun Indonesia memiliki satu sistem pendidikan nasional dan satu Undang-undang pendidikan yang berlaku, namun ada dua kementerian yang mengelola pendidikan, yaitu Kementerian Pendidikan dan Kementerian Agama. Inilah yang dimaksud dengan dualisme sistem pendidikan Indonesia. Awalnya, pendidikan Islam berada di luar system, sehingga dualism itu tidak begitu Nampak. Namun sejak tahun 1970an dualisme ini mulai mewujud seiring dengan diakuinya pendidikan Islam sebagai bagian dari sistem pendidikan nasional oleh Pemerintah Orde Baru. Tulisan ini mencoba merekonstruksi dualisme sistem pendidikan di Era Orde Baru dengan menggunakan metode kualitatif-hsitoris. Tulisan ini membuktikan bahwa sebenarnya dualisme pendidikan telah ada sebelum masa Orde Baru. Namun, di masa Orde Baru-lah dualisme itu muncul secara aksplisit, ketika pendidikan Islam diakui sebagai institusi resmi yang berbeda dengan pendidikan sekuler.

Kata Kunci: kurikulum ganda; Pendidikan Islam

How to Cite: Zuhdi, M. (2015). Construction of Dual Curriculum in Indonesian Education System During the New Order Government. TARBIYA: Journal Of Education In Muslim Society, 2(1), 47-60. doi:10.15408/tjems.v2i1.1819.

Permalink/DOI: http://dx.doi.org/10.15408/tjems.v2i1.1819 


\section{Introduction}

In 1998, Indonesia experienced a major turn around in its political system, the New Order government that controlled the country for 30 years lost power. President Suharto, an army general that lead the government during the era, stepped down from the presidency due to massive demonstrations that demanded a substantial change within the government.

During its 30 years of leadership, besides a number of controversial policies, the New Order government made a number of significant changes in the education sector. The changes included: significant development of the number of state funded schools, the reconstruction of school curricula, and the efforts of integrating Muslim schools into the national system. The latest was the most difficult policy to implement. In fact, a number of Muslim leaders rejected the policy and proposed to maintain the status quo of having Muslim schools independent from the secular system.

Realizing that they needed supports from the Muslim leaders, especially during the early years of their leadership, the government agreed to maintain the status quo. However, the government insisted that the Muslim schools should change their curricula significantly in order to be recognized as equal to secular schools. Muslim leaders agreed with the government's proposition, and hence the Indonesian education system recognized dual curriculum for the same level of schooling, i.e. general-school curricula and religious-school curricula.

The main problem with the existence of dual curricula was the equivalence of the content. The nature of dual curriculum is that each curriculum has its own strengths and uniqueness that others do not offer. In some cases, a school can employ dual curriculum and receive benefits from both sides. What happened in Indonesia was that the government recognized two forms of curriculum that offered similar levels of schooling and to similar groups of people. The question is then how the education authority ensure that the two curricula meet the rights of students to have a proper education?

In order to answer the question we need to know the nature of the dual education system in Indonesia, and to comprehend the structure of the recognized curricula.

\section{Previous studies}

The dual education phenomenon in Indonesia has been an issue that interests a number of scholars. Subhan (2012) identified that the dual system represents two sides of Indonesian academicians. The first belongs to those raised and educated in Western or secular kinds of environment. They follow the footsteps of secular education founded by the Dutch prior to the country's independence. The second belongs to Muslim scholars educated in the Middle East or in religious-based local educational institutions known as Pesantren and Madrasah.

From the political perspective, Sirozi's (2004) view is that the co-existence of two different education systems within an education authority indicated the existence of political or ideological problems. The co-existence is an "emergency political compromise". It indicated that despite the decision concerning the country's constitution, the two groups were not in agreement about the education system. This issue remained a major piece of homework for the Minister of Education and the Minister of Religion to reconcile so long as the dual system existed.

The government had taken several serious efforts to narrow the gap between the two systems. One of the major efforts was the 
creation of a tri-ministerial joint decree in 1975 . The decree, which focused on the improvement of Muslim schools, urged Madrasahs (Islamic based schools) (Islamic day schools) to improve their quality in order to be recognized equally with the secular schools. The decree, according to Zuhdi (2005), actually maintained the dual education system that already co-existed. In fact, it prolonged the reconciliation process between the two systems. Sirozi (2004) even makes the aanalysis that the co-existence of the two systems also indicated the unwillingness of the two groups to find an agreeable solution, and that the two groups were not sincere enough to find a solution.

The above studies, and many others, such as Steenbrink (1986), Dhofier (1995), and Maksum (1999), indicated that the Indonesian education system experienced dualistic standards that could not be reconciled time after time. While government regimes have changed overtime, the dualistic system remains in place, although the gap currently is not as wide. However, despite the fact that the New Order government was not able to reconcile the two systems, it was able to significantly narrow the gaps through the reconciliation of curricula.

\section{Reseach Framework}

The study is conducted using a qualitativehistorical method, meaning that the data are gathered from various resources using the qualitative approach combined with a historical perspective. The main source of the study is the Report of the Minister of Education and Culture published in 1997. Other sources include articles, books and documents containing useful information on education during the New Order government.

The data collected are reviewed and analyzed using a social constructionist approach on curriculum (Goodson, 1994). It is believed that any curriculum is never detached from the society it serves. The contents of any given curriculum somehow represent the expectation of the society. The construction of curriculum is reciprocally influenced by the dynamic of the society. Therefore, this study also identified key factors that influence the dynamic of the society.

While there are many definitions concerning curriculum, as Schubert (1986) identifies, this paper focuses on the government policy of what to teach. In other words, curriculum in this context is understood as the written document or Curriculum as a Prescription, as Goodson (1994) put it. This means that while acknowledging various aspects of education and educational environment that are influential to children, this paper focuses on how the education authority responded to the needs of the society through the creation of curriculum policy.

This paper identifies different curricula that existed during the given political era and makes some comparisons between two curricula produced by two different ministries. The analysis will focus on social and political influences on curriculum policy.

\section{Indonesian Education during the New Order}

Indonesian education under the administration of the Indonesian government began in August 19, 1945 when President Soekarno appointed Mr. Ki Hadjar Dewantara, a prominent figure in education, as the Minister of Education. In the beginning, the government formally recognised secular education, inherited from the Dutch, as the only education system applied in Indonesia. However, education has its own roots in Indonesia. In addition to the Dutch system, other types of education had existed in the country to serve the country's young generation who, for various reasons, could not attend the secular Dutch schools. With respect to other religion-based institutions, Muslim schools were the biggest institutions 
existed outside the Dutch based school system. Still continued until now, there were two types of Muslim schools existed in Indonesia: Madrasah (Day school) and Pesantren (boarding school).

The recognition of a secular system as the mainstream of Indonesian education system was in fact, relevant to the country's principles that accommodated various different faiths. The principles respected existing religions and protected the rights of its citizens to observe religious duties they believe in. It included the believers' rights to create an educational institution that could preserve their religion from generation to generation. Hence, without any support from the government, religion-based schools, that had existed before the country's independence, continued to exist and carried out their missions to educate Indonesia's young generations.

In 1945, an adhoc committee, known as BPKNIP (the Working Body of the Central Indonesia National Committee) was created and made several recommendations to the Ministry of Education. Here are the recommendations as quoted by The Ministry of Education:

1. In order to recognize a new society, basic changes are required in the development of education and teaching. Individualism, which was the present orientation, should be changed to understand high morality and humanity. Education and teaching should guide students to become responsible citizens.

2. To strengthen the unity of society, there should only be one type of school for all people regardless of social status. It also needs to be remembered that according to basic social justice, all schools have to be opened to all people, male or female.

3. The desirable method to be used in schools is the one based on a work school system so the participants can develop skills related to their work in as broad a manner as possible. Apart from the usual schools, there should also be a 'school' to cater the educational needs of adults to help overcome the illiteracy problem, and furthermore this system should be backed up by learning centers, to ensure that the basic guidelines in point 1 above are adhered to. There is also a need for a 'school' for community leaders in each important field of work. There is a need for a special office to manage adult education.

4. It is desirable for religious education to get a special place and proper attention, without encroaching on the freedom of those who wish to follow their chosen faith. For its operation, the Ministry should negotiate with the Working Body of Central Indonesia National Committee.

5. Madrasahs and Pesantrens which in essence represent both sources and facilities for mass education which are firmly rooted in the minds of the people and national culture, should receive more attention and real assistance from the Government, both for the organizational and material aspects.

6. Higher or tertiary education should be developed in as broad a manner as possible by using foreign manpower and expertise. Apart from that, attempts should also be made to send Indonesian students overseas for education in order to fill the nation's needs.

7. Compulsory schooling should be develop step by step and implemented within the next ten years so that all school age children have the opportunity to participate in primary school for at least six years (six years of school for every Indonesian child).

8. Technical and economic education, particularly in the field of agriculture, 
industry, shipping and fisheries should receive special attention.

9. Health and sports education should be carried out regularly to promote harmonious development of a society that is both fit and intelligent.

10. Primary school should not be charged with an entry fee. For secondary and tertiary education a fee regulation paying system and a support avoiding learning constraint for students who come from families with financial problem.

(The Minister of Education and Culture, 1997)

Following up the above recommendations, particularly points 4 and 5 , the government started to pay attention to religious education. Therefore, after the government created the Ministry of Religious Affairs whose duties include managing the teaching of religious subjects in public schools and maintaining the government's relations with Muslim schools, i.e. Madrasahs and Pesantrens. However, this did not mean that the government recognized Muslim schools as part of the national education system. Instead, the government acknoweldged the existence of those institutions, but did not recognize them as formal education. Since then, the Government has continued to develop the secular education system, while at the same time the Muslim schools have continued to run their programs and catered for the demands of Muslim society. Very little effort seemed to have been taken to bring the two systems closer.

When the New Order Government took power, the relationship between the two systems started to change. The Government wanted to manage education solely under the Ministry of Education, a plan known as single roof education policy. The effort, however, was not easy and was considered unsuccessful. For various reasons, the Muslim schools refused to be managed by the Ministry of Education, and insisted that Madrasahs and Pesantrens remained under the coordination and supervision of the Ministry of Religious Affairs. Avoiding a social clash between the two proponents, the Government maintained the status quo with several conditions (for further discussion, see Zuhdi, 2005). As a result, the dualism of educational management at the national level remained in place, noting that the government was able to narrow the gap through the creation of the standardized curriculum for Muslim schools in 1976. This marked the beginning of the official co-existence between secular and religious curricula recognized by the state.

In order to better understand the context of Education in Indonesia, Table no. 1 below describes the structure of schooling as applied during the New Order. There has been very little change in the structure of schooling in Indonesia since then.

Table 1. The structure of Schooling

\begin{tabular}{|c|c|c|c|c|}
\hline \multirow{3}{*}{$\begin{array}{l}\text { Official } \\
\text { School } \\
\text { Age }\end{array}$} & \multirow[t]{3}{*}{ Level } & \multicolumn{3}{|l|}{ Type of School } \\
\hline & & \multicolumn{2}{|l|}{ Academic } & Vocational \\
\hline & & \multicolumn{3}{|l|}{$\begin{array}{l}\text { Ministry of } \\
\text { Religious } \\
\text { Affairs }\end{array}$} \\
\hline $\begin{array}{l}25 I \\
\text { above }\end{array}$ & \multirow[t]{5}{*}{ Education } & $\begin{array}{l}\text { Post Graduate } \\
\text { in Islamic } \\
\text { Studies }\end{array}$ & \multicolumn{2}{|l|}{$\begin{array}{l}\text { Post } \\
\text { Graduate }\end{array}$} \\
\hline 24 & & \multirow{2}{*}{$\begin{array}{l}\text { Graduate in } \\
\text { Islamic Studies }\end{array}$} & \multirow[t]{2}{*}{ Graduate } & \\
\hline $\begin{array}{l}23 \\
22\end{array}$ & & & & \\
\hline 21 & & \multirow{2}{*}{$\begin{array}{l}\text { Bachelor in } \\
\text { Islamic Studies }\end{array}$} & \multirow[t]{2}{*}{ Bachelor } & Undergraduate \\
\hline $\begin{array}{l}20 \\
19\end{array}$ & & & & $\begin{array}{l}\text { Diploma } \\
\text { (Academy) }\end{array}$ \\
\hline 18 & Upper & \multirow{3}{*}{$\begin{array}{l}\text { Muslim High } \\
\text { School } \\
\text { (Madrasah } \\
\text { Aliyah) }\end{array}$} & \multirow{3}{*}{$\begin{array}{l}\text { General } \\
\text { High } \\
\text { School } \\
\text { (SMU) }\end{array}$} & Vocational \\
\hline 17 & Secondary & & & High school \\
\hline 16 & School & & & \\
\hline 15 & Lower & Muslim Lower & \multirow{3}{*}{\multicolumn{2}{|c|}{$\begin{array}{l}\text { Junior Secondary School } \\
\text { (SMP) }\end{array}$}} \\
\hline 14 & Secondary & \multirow{2}{*}{$\begin{array}{l}\text { Secondary } \\
\text { School } \\
\text { (Madrasah } \\
\text { Tsanawiyah) }\end{array}$} & & \\
\hline 13 & School & & & \\
\hline 12 & \multirow{7}{*}{$\begin{array}{l}\text { Primary } \\
\text { School }\end{array}$} & \multirow{7}{*}{$\begin{array}{l}\text { Muslim } \\
\text { Primary School } \\
\text { (Madrasah } \\
\text { Ibtidaiyah) }\end{array}$} & \multirow{7}{*}{$\begin{array}{l}\text { Primary } \\
(\mathrm{SD})\end{array}$} & \\
\hline 11 & & & & \\
\hline 10 & & & & \\
\hline 9 & & & & \\
\hline 8 & & & & \\
\hline 7 & & & & \\
\hline 6 & & & & \\
\hline 5 & \multirow[t]{3}{*}{ Pre-school } & \multirow{3}{*}{$\begin{array}{l}\text { Muslim } \\
\text { Kindergarten } \\
\text { (RA) }\end{array}$} & \multirow{3}{*}{\multicolumn{2}{|c|}{$\begin{array}{l}\text { Kindergarten } \\
\text { (non-denominational) }\end{array}$}} \\
\hline 4 & & & & \\
\hline 3 & & & & \\
\hline
\end{tabular}




\section{Regulations}

The New Order Government worked under two National Education Laws, namely Education and Instruction Law Number 4, 1950 and the National Education System Law Number 2, 1989. The 1950 Law was created during the Old Order regime and did not pay much attention to the existence of Muslim schools. As a result, Muslim schools, which were mostly private, continued to carry out their missions with very little intervention from the government.

To some extent the independency of Muslim schools allowed them to have more space and authority to create their own programs. However, given that most private Muslim schools were poorly-funded, this can also be seen as government's negligence of the rights of education for Indonesian children. Furthermore, the laxity was not only true for financial matters, but also for the education content. It seemed that the Government had very little to say about what Muslim schools should teach to their children. Muslim leaders had an ambivalent position on this. On one side, some enjoyed the independency of the Muslim education system from the government. On the other side, they felt marginalized from the national education system.

Law Number 2 on the National Education System was released almost 40 years after the first law was sanctioned. Passed in 1989, Law Number 2 on National Education System put Muslim schools in a much better position within the system. The Law officially recognized Muslim schools as formal education and equivalent to secular schools in terms of programs and certificates. It is important to note, however, that the inclusion of Muslim schools into the national education system did not entirely integrate Muslim schools into the system. There were two things that remained unchanged. First, the authority of supervising Muslim schools belonged to the Ministry or Religious Affairs. Second, Muslim schools had their own curricula complementary to the secular curricula.

In addition to the aforementioned education laws, there were a number of government regulations that tried to bridge the gap between the two systems. Those were:

1. Presidential Decree No. 34/1972 on Functional Responsibility of Education and Training. This decree authorizes the Ministry of Education to manage all aspects and forms of education. This regulation was also known as a single roof policy in education

2. Presidential Instruction No. 15/1974 on the Implementation of the Presidential Decree No. 34/1972.

3. Three-Minister Joint Decree on March 24, 1975 on the Improvement of the Quality of Education in Madrasahs. This decree was signed by the Minister of Education and Culture, the Minister of Religious Affairs, and the Minister of Home Affairs.

4. Two-Minister Joint Decree 1984 on Standardization of Curricula for Nondenominational School and Madrasah. This decree was signed by the Minister of Education and the Minister of Religious Affairs.

All of the above decrees were created to accommodate the existence of Muslim schools within the national education system. The regulations mostly focus on the quality of education with special references to the curricula.

\section{The Construction of Dual Curriculum}

The Curricula prior to 1975

In 1975, the government released a joint decree signed by three ministers, i.e. the Minister 
of Education and Instruction, the Minister of Religious Affairs and the Minister of Home Affairs. This decree actually set major changes in curricula, especially those related to Islamic education.

There were at least three different types of curriculum: general public school curricula created by the Ministry of Education, official Islamic school curricula created by the Ministry of Religion and private Muslim school curricula. The following tables compare the structure of subjects in every curriculum at three different levels of schooling before 1975 .

Table 2. Comparison of Primary School Subjects Before 1975

\begin{tabular}{|c|c|c|c|}
\hline No & $\begin{array}{l}\text { Primary } \\
\text { School } \\
\text { (Ministry of } \\
\text { Education) } \\
\text { - } 6 \text { years } \\
\text { program - }\end{array}$ & $\begin{array}{l}\text { Government-affiliated } \\
\text { Muslim Primary School } \\
\text { (Ministry of Religious } \\
\text { Affairs) } \\
\text { - 6/7 years program- }\end{array}$ & $\begin{array}{l}\text { Pesantren } \\
\text { Krapyak } \\
\text { Yogyakarta } \\
\text { (Ex. Of Private } \\
\text { Muslim Primary } \\
\text { School) } \\
\text {-4 years program } \\
\text { - }\end{array}$ \\
\hline 1. & $\begin{array}{l}\text { Religious } \\
\text { Education }\end{array}$ & $\begin{array}{l}\text { Reading and } \\
\text { Understanding the Quran }\end{array}$ & $\begin{array}{lr}\text { Reading } & \text { the } \\
\text { Quran } & \text { (Holy } \\
\text { book) } & \end{array}$ \\
\hline 2. & $\begin{array}{l}\text { Citizenship } \\
\text { Education }\end{array}$ & The Prophet's Traditions & $\begin{array}{l}\text { Understanding } \\
\text { the Quran }\end{array}$ \\
\hline 3. & $\begin{array}{l}\text { Indonesian } \\
\text { Language }\end{array}$ & Theology & $\begin{array}{l}\text { The Prophet's } \\
\text { Traditions }\end{array}$ \\
\hline 4. & $\begin{array}{l}\text { Ethnic } \\
\text { Language }\end{array}$ & Islamic Ethics/Manner & Theology \\
\hline 5. & Sports & Islamic law & Islamic Law \\
\hline 6. & Arithmethics & History of Islam & $\begin{array}{l}\text { Writing Arabic } \\
\text { Scripts }\end{array}$ \\
\hline 7. & $\begin{array}{l}\text { Natural } \\
\text { Sciences }\end{array}$ & Arabic language & Arabic Grammar \\
\hline 8. & Arts & Citizenship & Arabic Language \\
\hline 9. & $\begin{array}{l}\text { Home } \\
\text { Economics }\end{array}$ & Indonesian Language & $\begin{array}{l}\text { Memorization of } \\
\text { Arabic Proverbs }\end{array}$ \\
\hline 10. & $\begin{array}{l}\text { Special skill } \\
\text { education }\end{array}$ & $\begin{array}{l}\text { Physical Education } \\
\text { (Sport) }\end{array}$ & $\begin{array}{l}\text { Indonesian } \\
\text { Language }\end{array}$ \\
\hline 11. & & Ethnic Language & Math \\
\hline 12. & & Math & History \\
\hline 13. & & Natural Science & Geography \\
\hline 14. & & Arts & Biology \\
\hline 15. & & Handwork/Handicrafts & \\
\hline 16. & & Farming (special class) & \\
\hline 17. & & $\begin{array}{l}\text { Technical Skills (Special } \\
\text { class) }\end{array}$ & \\
\hline 18. & & Business (Special class) & \\
\hline
\end{tabular}

Note:

Subjects in the highlighted area are considered as Islamic subjects. Source: Adapted from The Minister of Education (1997, 126), Maksum (1999, 143-144), Yunus (1996, 283)
Table 3. Comparison of Lower Secondary School Subjects Before 1975

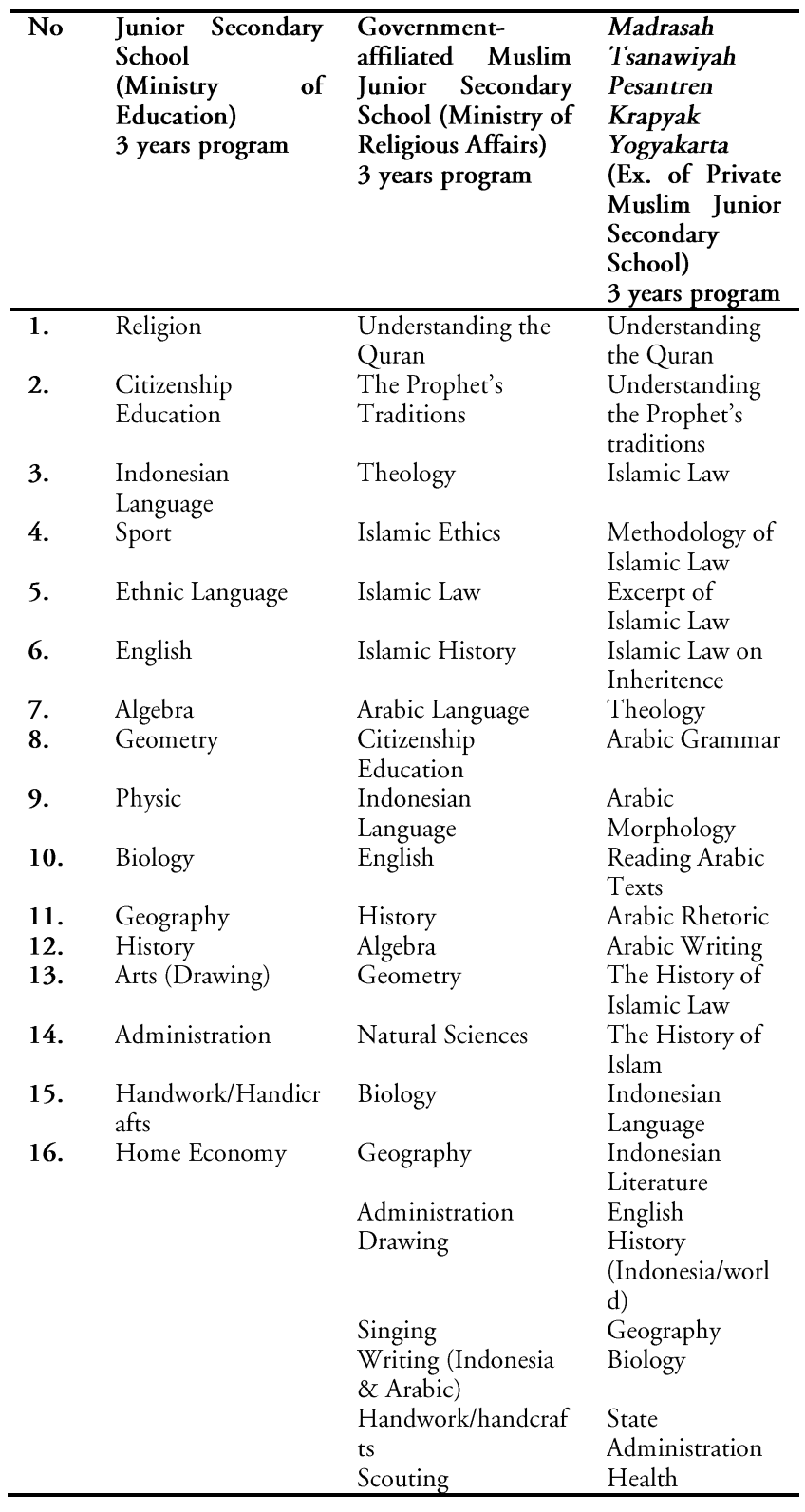

Note:

Subjects in the highlighted area are considered as religionoriented subjects.

Source: Adapted from The Minister of Education (1997, 133), Maksum (1999, 143-144), Yunus (1996, 284) 
Table 4. Comparison of Upper Secondary School Subjects Before 1975 (Academic Programs)

\begin{tabular}{|c|c|c|c|}
\hline No & $\begin{array}{l}\text { High School } \\
\text { (Ministry of } \\
\text { Education) } \\
3 \text { years } \\
\text { program }\end{array}$ & $\begin{array}{l}\text { Government- } \\
\text { affiliated Muslim } \\
\text { High School } \\
\text { (Ministry of } \\
\text { Religious Affairs) } \\
3 \text { ys program }\end{array}$ & $\begin{array}{l}\text { Qismul 'Ali } \\
\text { Pesantren } \\
\text { Krapyak } \\
\text { Yogyakarta } \\
\text { (Example of } \\
\text { Private Muslim } \\
\text { High School) } \\
2 \text { yrs program } \\
\end{array}$ \\
\hline 1. & Religion & $\begin{array}{l}\text { Understanding the } \\
\text { Quran }\end{array}$ & $\begin{array}{l}\text { Methodology of } \\
\text { Islamic Law }\end{array}$ \\
\hline 2. & $\begin{array}{l}\text { Civic } \\
\text { Education }\end{array}$ & $\begin{array}{l}\text { Understanding the } \\
\text { Prophet's traditions }\end{array}$ & Islamic Law \\
\hline 3. & $\begin{array}{l}\text { Indonesian } \\
\text { language }\end{array}$ & Theology & Islamic History \\
\hline 4. & Sport & $\begin{array}{l}\text { Islamic law and Its } \\
\text { Methodology }\end{array}$ & Arabic Language \\
\hline 5. & $\begin{array}{l}\text { Indonesian } \\
\text { Literature*) }\end{array}$ & $\begin{array}{l}\text { The History of } \\
\text { Islamic Law }\end{array}$ & $\begin{array}{l}\text { History of } \\
\text { Islamic law }\end{array}$ \\
\hline 6. & Geography & The History of Islam & Arabic Literature \\
\hline 7. & Math & Arabic language & $\begin{array}{l}\text { Indonesian } \\
\text { Language }\end{array}$ \\
\hline 8. & Physics & $\begin{array}{l}\text { Islamic History and } \\
\text { Civilization }\end{array}$ & Math \\
\hline 9. & Chemistry & Citizenship & Geography \\
\hline $\begin{array}{l}10 . \\
11 .\end{array}$ & $\begin{array}{l}\text { Biology } \\
\text { Economics }\end{array}$ & $\begin{array}{l}\text { Indonesian Language } \\
\text { English }\end{array}$ & Science \\
\hline 12. & Drawing & $\begin{array}{l}\text { Physical Education } \\
\text { (Sport) }\end{array}$ & \\
\hline 13. & English & Science/Math & \\
\hline 14. & $\begin{array}{l}\text { Home } \\
\text { Economy }\end{array}$ & Natural Sciences & \\
\hline 15. & Handcrafts & Biology & \\
\hline 16. & History ${ }^{*}$ ) & Physics & \\
\hline 17. & Geography*) & Chemistry & \\
\hline 18. & Culture *) & Geography & \\
\hline 19. & $\begin{array}{l}\text { Ethnic } \\
\text { Language *) }\end{array}$ & Biology & \\
\hline 20. & $\begin{array}{l}\text { Algebra \& } \\
\text { Analytics **) }\end{array}$ & Economics & \\
\hline 21. & $\begin{array}{l}\text { Goneometry } \\
* *)\end{array}$ & Trading & \\
\hline 22. & Stereometry ${ }^{* *}$ ) & $\begin{array}{l}\text { Administration } \\
\text { Arts } \\
\text { Handicraft } \\
\text { Scouting }\end{array}$ & \\
\hline
\end{tabular}

Note:

*) For Social Science Class only

**) For Science Class only

***) Subjects in the highlighted area are considered as Islamic subjects

****) Most Islamic schools did not have academic high schools, the most common form of Islamic high school was high school for pre-service teachers.

Source: Adapted from The Minister of Education (1997), Maksum (1999), Yunus (1996)
As the above tables show, religion-oriented subjects received more attention in Muslim schools, especially in the private Muslim schools. The proportion was even bigger when the actual study hours are included. The high proportion of religious oriented subjects can be seen in two different perspectives. First, for Muslim leaders, their existence was very important to preserve religious teachings among the believers, so that children will grow and have sufficient knowledge of their own religion, in addition to "secular" knowledge. Second, the government, on the contrary, believed that the high proportion of religious oriented subjects could lead children to understand their religious teaching only and pay less attention to other (i.e. secular) subjects. As a result, children would find difficulties when they had to integrate into wider society and especially in finding jobs in the future. This also potentially created a big gap between students of secular schools and students of religious schools. A gap that potentially became a source of conflict in the future.

The Ministry of Religious Affairs tried to minimize the gap by proposing the government curricula for Muslim schools, as the above tables show. The government curricula basically minimized the proportion of religious oriented subjects and provided more space for nonreligion oriented subjects. However, the curricula were only applicable in government funded Muslim schools, which were far fewer in number than those of private institutions.

There were several other efforts that indicated that the government was continued to minimize the gap. Among them were the release of Presidential Decree No. 34/1972 on Functional Responsibility of Education and Training, and Presidential Instruction No. $15 / 1974$ on the Implementation of the Presidential Decree No. 34/1972. The two regulations mandated the Minister of Education to take over educational supervision in all 
different ministries, including those under the Ministry of Religious Affairs. However, Muslim leaders rejected the idea and maintained that it was the role of the Ministry of Religion to supervise private Muslim schools.

Zuhdi (2005) observed several reasons why Muslim leaders were reluctant to accept the idea of having Muslim schools supervised by the Ministry of Education. First, the Ministry of Education did not have experts on religious education. Second, there were a proposal in 1961 from the People's Consultative Assembly to merge Muslim schools with secular schools. Third, between 1965 - 1968 Indonesia experienced massive clashes between the communists and Muslims and Muslim leaders were afraid that the remaining communists within the government would abolish Muslim schools if they were under the Ministry of Education. Those reasons prompted Muslim leaders to preserve the status quo of having Muslim schools under the Ministry of Religious Affairs.

Rejection from Muslim leaders made the Government reserve its decision to merge authority over Muslim schools into the Ministry of Education. As an alternative, the Government released a joint decree in March 1975. The main objective of the decree was improving the quality of Muslim schools without transmitting their authority to the Ministry of Education.

Following the above decree, Muslim schools were required to change their curricula to improve their educational quality and to make themequivalent to secular schools. One of the major changes of the curricula was that the composition of religious oriented subjects was reduced to $30 \%$ of the curricula (Muhammad Zuhdi, 2005). Furthermore, Saleh (1976) identified three significant implications of the joint decree: First, the diploma/certificate of madrasah (Muslim School) is considered equivalent to that of the same level at secular school; second, madrasah's graduates could continue their education at the upper level of secular school; third, existing madrasah students could transfer to a secular school at the same level, and vice versa.

When the Ministry of Education released a set of school curricula for all levels of schooling in 1975, the Ministry of Religious Affairs followed this and created curricula for Muslim schools in 1976. The curricula were created as a follow up to the joint decree. All madrasahs were required to implement the curricula with or without additional subjects of their own. Otherwise, the government would not recognise them as formal schooling.

As a response, there were three types of Madrasahs following the implementation of the joint decree and the 1976 curricula. The first was madrasahs that adopted the government curricula without any modification. The second was madrasahs that adopted the curricula with modification, mainly adding some religious subjects of their own without changing the prescribed curricula. The third was madrasahs that maintained their own curricula and rejected the implementation of the government curricula. The latter were private madrasahs or pesantrens (Muslim boarding school) that were not satisfied with the government curricula.

After a few years of implementation, the 1975/1976 curricula were reviewed and revised to better serve students. The revised curricula were known as 1984 curricula for Secular Schools and 1986 Curricula for Religion Oriented Schools. The following tables show the composition of the 1984/1986 curricula. 
Table 5. Comparison of Primary School Curricula 1984/1986

\begin{tabular}{llll}
\hline No & $\begin{array}{l}\text { Primary School } \\
\text { (Ministry }\end{array}$ & of & $\begin{array}{l}\text { Government-affiliated Muslim } \\
\text { Primary School } \\
\text { (Ministry of Religious Affairs) } \\
\end{array}$ \\
& -1984 curriculum - & -1986 Curiculum-
\end{tabular}

\begin{tabular}{|c|c|c|}
\hline 1. & Religious Education & $\begin{array}{l}\text { The Quran and the Prophet's } \\
\text { Tradition }\end{array}$ \\
\hline 2. & $\begin{array}{l}\text { Pancasila Moral } \\
\text { Education }\end{array}$ & Theology and Ethics \\
\hline 3. & $\begin{array}{l}\text { History of the } \\
\text { Struggle for } \\
\text { Nationhood }\end{array}$ & Islamic Law \\
\hline 4. & Indonesian Language & Islamic History \\
\hline 5. & Social Sciences & Arabic Language \\
\hline 6. & Math & Pancasila Moral Education \\
\hline 7. & Natural Sciences & $\begin{array}{l}\text { History of the Struggle for } \\
\text { Nationhood }\end{array}$ \\
\hline 8. & Sports and Health & Indonesian Language \\
\hline 9. & Arts & Social Sciences \\
\hline 10. & Special skill & Math \\
\hline 11. & Ethnic Language & Natural Sciences \\
\hline 12. & & Sports and Health \\
\hline 13. & & Arts Education \\
\hline 14. & & Special Skills \\
\hline 15. & & Ethnic language \\
\hline
\end{tabular}

Source: The Minister of Education, 1997, 242 and Daulay, 2001, 91-92

Table 6. Comparison of Lower Secondary School Curricula 1984/1986

\begin{tabular}{|c|c|c|}
\hline \multirow[t]{6}{*}{ No } & \multirow{6}{*}{$\begin{array}{l}\text { Lower Secondary School } \\
\text { (Ministry of Education) } \\
-1984 \text { curriculum - }\end{array}$} & \multirow{6}{*}{$\begin{array}{l}\text { Madrasah Tsanawiyah/ } \\
\text { MuslimLower Secondary } \\
\text { School } \\
\text { (Ministry of Religious } \\
\text { Affairs) } \\
\text { - } 1986 \text { Curiculum- }\end{array}$} \\
\hline & & \\
\hline & & \\
\hline & & \\
\hline & & \\
\hline & & \\
\hline \multirow[t]{2}{*}{1.} & Religious Education & The Quran and the \\
\hline & & Prophet's Tradition \\
\hline \multirow[t]{2}{*}{2.} & Pancasila Moral & Theology and Ethics \\
\hline & Education & \\
\hline 3. & History of the Struggle for & Islamic Law \\
\hline \multirow[t]{2}{*}{4.} & Physical Education & Islamic History \& \\
\hline & & Civilization \\
\hline 5. & Arts Education & Arabic Language \\
\hline 6. & Indonesian Language & Pancasila Moral Education \\
\hline 7. & English & Indonesian Language \\
\hline 8. & Ethnic Language & $\begin{array}{l}\text { History of the Struggle for } \\
\text { Nationhood }\end{array}$ \\
\hline 9. & Social Sciences & English \\
\hline 10. & Mathematics & Ethnic language \\
\hline 11. & Biology & Social Sciences \\
\hline 12. & Physics & Mathematics \\
\hline 13. & Skill & Biology \\
\hline 14. & & Physics \\
\hline 15. & & Sports and Health Education \\
\hline 16. & & Arts Education \\
\hline 17. & & Special Skills \\
\hline
\end{tabular}

Source: The Minister of Education (1997) and Daulay (2001)
Table 7. Comparison of Upper Secondary School Curricula 1984/1986

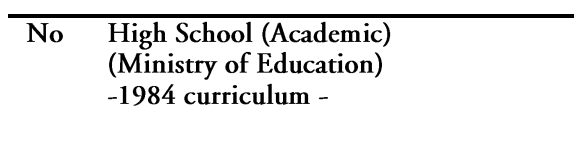

Madrasah Aliyah/

Muslim High School

(Ministry of Religious

Affairs)

- 1986 Curiculum-

\begin{tabular}{|c|c|c|}
\hline 1. & Religious Education & $\begin{array}{l}\text { The Quran and the Prophet's } \\
\text { Tradition }\end{array}$ \\
\hline 2. & Pancasila Moral Education & Theology and Ethics \\
\hline 3. & History of Struglle for Nationhood & Islamic Law \\
\hline 4. & Indonesian Language and Literature & $\begin{array}{l}\text { Islamic History \& } \\
\text { Civilization }\end{array}$ \\
\hline 5. & History (Indonesia and the World) & Arabic Language \\
\hline 6. & Economics & Pancasila Moral Education \\
\hline 7. & Geography & $\begin{array}{l}\text { Indonesian Language and } \\
\text { Literature }\end{array}$ \\
\hline 8. & Physical Education & $\begin{array}{l}\text { History of the Struggle for } \\
\text { Nationhood }\end{array}$ \\
\hline 9. & Arts & $\begin{array}{l}\text { History (Indonesia and the } \\
\text { World) }\end{array}$ \\
\hline 10. & Skills & Economics \\
\hline 11. & Mathematics & Geography \\
\hline 12. & Biology & Biology \\
\hline 13. & Physics & Physics \\
\hline 14. & Chemistry & Chemistry \\
\hline 15. & English & Mathematics \\
\hline & Elective subject (major): & English \\
\hline 16. & - Mathematics & $\begin{array}{l}\text { Sports and Health } \\
\text { Education }\end{array}$ \\
\hline 17. & - English & Arts Education \\
\hline 18. & - Biology $\left.{ }^{*}\right)$ & Special Skills \\
\hline 19. & - Physics*) & $\begin{array}{l}\text { Elective subject (majoring } \\
\text { religious sciences): }\end{array}$ \\
\hline 20. & - Chemsitry*) & - Quranic Exegesis ****) \\
\hline 21. & - Accounting ${ }^{* *}$ ) & $\begin{array}{l}\text { - Methodology of study the } \\
\text { Prophet's Tradition }{ }^{* * * *} \text { ) }\end{array}$ \\
\hline 22. & - Sociology/Anthropology ${ }^{* *}$ ) & $\begin{array}{l}\text { - Methodology of Islamic } \\
\left.\text { Law }^{* * * *}\right)\end{array}$ \\
\hline 23. & - Government Administration ${ }^{* *}$ ) & $\begin{array}{l}\text { - The History of Islamic } \\
\text { Law }{ }^{* * * *} \text { ) }\end{array}$ \\
\hline 24. & $\begin{array}{l}\text { - Foreign Language (other than } \\
\text { English) }{ }^{* *} \text { ) }\end{array}$ & $\begin{array}{l}\text { - Discourse on Islamic } \\
\text { Theology }{ }^{* * * *} \text { ) }\end{array}$ \\
\hline 25 . & - Cultural History ${ }^{* * *}$ ) & - History of Religions ${ }^{* * * *}$ ) \\
\hline 26. & - Literature ${ }^{* * *}$ ) & - Mathematics ${ }^{* * * *}$ ) \\
\hline 27. & - Ethnic Languages ${ }^{* * *}$ ) & \\
\hline \multicolumn{3}{|l|}{ Note: } \\
\hline$*)$ & \multirow{2}{*}{\multicolumn{2}{|c|}{$\begin{array}{l}\text { Elective subjects offered for classes majoring in sciences } \\
\text { only } \\
\text { Elective subjects offered for classes majoring in social } \\
\text { sciences only }\end{array}$}} \\
\hline$* *)$ & & \\
\hline$* * *)$ & $\begin{array}{l}\text { Elective subjects offered fo } \\
\text { only }\end{array}$ & sses majoring in culture \\
\hline$* * * *)$ & $\begin{array}{l}\text { Elective subjects offered for } \\
\text { sciences only. For classes } \\
\text { sciences or culture existed in } \\
\text { subjects are similar with thos }\end{array}$ & $\begin{array}{l}\text { ses majoring in religious } \\
\text { oring in sciences, social } \\
\text { drasah aliyah, the elective } \\
\text { regular high school. }\end{array}$ \\
\hline
\end{tabular}

Source: The Minister of Education, 1997, 248 and Daulay, 2001, 94

The 1986 Muslim school curricula simplified the contents of religious teaching into five subjects: Arabic language (Bahasa Arab), 
Understanding the Quran and the Prophet's traditions (Quran-Hadits), Islamic Theology and Ethics (Aqidah-Akhlak), Islamic Law (Fiqh), and Islamic History and Civilization (Sejarah Kebudayaan Islam). In this way, Muslim students could have more time to study non religion oriented subjects such as Science, Math, English and Social sciences. However, students who wished to learn more religion-orientedsubjects could take classes majoring in religious sciences at high school level.

\section{Discussion}

As a relatively young country, consisting of various ethnic groups and religious adherents, Indonesia is a fragile one. The founding fathers of the country had been able to unite those differences into one single independent country named Indonesia. It was not easy for the initial government to maintain the unity, as different groups had different agendas to promote and different ways to negotiate. Wars and conflicts were part of the era, and hence the acceptance of one group to another cannot be taken for granted. The founding fathers formulated a national ideology known as Pancasila (five principles). This ideology represented the major ideological groups, namely nationalists, Muslims, and communists.

Since the very beginning of the country's development, the issue of religion and ideology became one of the crucial topics for discussion. Each group argued that their ideological position was the best option for the country. It was at this point, Soekarno, the then Indonesian first President, led different groups of community leaders and came up with the formulation of Pancasila as an acceptable solution for majority. Pancasila consists of five principles: 1 . Belief in one God; 2. Humanity based on justice and civilization; 3. The unity of Indonesia; 4. People's sovereignty based on wisdom and representation. 5. Social justice for all Indonesians. These principles saved Indonesia from the possibility of disintegration caused by different ideological point of views. However, the challenges continued to exist. The communists and the Islamists, especially those who were unhappy with Soekarno's solution, continued to treat the country with various political distractions. Therefore, the discussion about the relationship between religion and state continued to exist.

Religious education is among the major issues that have concerned every government in Indonesia. It took years for the Old Order government to produce an education law due to, among other things, long discussions on religious education (Lee Kam Hing, 1995). The debate over the existence of religious education in public schools that sparked controversy indicated that the issue of religion remained a very important, yet sensitive, issue. This was not only true in the education sector but in other aspect's of government administration as well.

Government's decision to impose the coexsitence of secular and religion-oriented curricula should be seen from the above perspective. Having a single education system was an ideal situation, but accommodating different perspectives and interests on education was unavoidable.

There were two major issues related to coexistence of religious-oriented and secular curricula: Maintaining national's unity and the changes in society.

\section{Maintaining nation's unity}

There were two reasons why the government insisted on pulling the Muslim schools into the national education system. The first was the disintegration treat. As previously mentioned, different political and ideological groups had their own agenda to aim for. The 
different agendas that each group had potentially became national threats. One of the potential threats came from the Islamist political groups who maintained their argument of creating Indonesia as an Islamic state. Therefore, the government found it critically important to supervise Muslim schools, where the ideology of Islam was disseminated.

History shows that the government was unable to fully integrate the existing Muslim schools into the national (secular) education system, as Muslim leaders preferred to be supervised by the Ministry of Religious Affairs. However, as the Ministry of Religious Affairs is a government institution, it is not difficult to supervise Muslim schools so long as they trust the Ministry of Religious Affairs. The introduction of government curricula for Muslim schools indicated that the government could ensure that the Muslim schools did not teach separation or any political agenda that could jeopardize national integration

The second reason was reducing the gap between communities. While secular schools were open for every citizen regardless of their religion and ethnicity, a lot of Muslim parents preferred Muslim schools (madrasah) for their children's education. They assumed that religious instructions were far more important than secular sciences, as they believed that they only live temporarily in the world, but forever in the hereafter. Before the New Order era, madrasahs focused more on teaching religious subjects and paid little attention to other subjects. The long term impact of this was that pesantren and madrasah graduates found it difficult to integrate into the larger plural society, especially when it came to finding jobs or employment. They could only become religious teachers or preachers in communities where they live, while the opportunities to become professional religious teachers or preachers were very limited.
The increasing proportion of non-religion oriented subjects in the madrasah curricula allowed Muslim students to learn various aspects of knowledge, skills and values. Knowledge of social and natural sciences, various life-skills, and civic values were among important things promoted through the modernized madrasah curricula.

The co-existence of dual curricula represented different views on the importance of education and religious education within the larger society. While the majority of Indonesian people hold a strong belief that religion is very important to their lives, their views of religious education were not singular. Some believed that religious education should be part of education in general, and even become the focus of national education, and hence the government should give more attention to religious education. Others believed that religion as well as religious education is a personal preference, and hence the government, and the public schools, should not be responsible for religious education.

\section{Social changes}

Major social changes occured not only in Indonesia but also in other countries that found independence after the Second World War. Political and economic development became the driving factors of the social changes. At the same time, Western values and ways of life started to be introduced, such as industrialization, work ethics, and democratic political systems. All of these required active participants from the society at large. In other words, people of the country were involved in developing the country directly or indirectly.

Following the fall of the Old Order regime in 1968, Indonesia experienced a new political atmosphere. The New Order government brought about political and economic stability by which people can carry on their daily 
activities in a more predictable situation. With that in mind, we should see education as an important aspect of people's lives. More parents, including Muslim ones, paid attention to formal education. Hence, there were unspoken expectations from the parents that they wanted Muslim schools to change. Steenbrink observed, "...this is because pesantren [a form of Muslim school] can no longer accommodate the needs of modern life, where everybody needs a job, while most of the pesantrens only offer solutions for life after this life" (Steenbrink, 1986).

Government intervention in Muslim school's curricula can be seen from two different perspectives. The first is political intervention in education; meaning that government with its political power influenced the substance of the curricula. The second perspective is that government facilitated the needs of the larger Muslim society that demanded changes in Muslim schools.

As an open society, Indonesian Muslim society, with influences from both the Western and Eastern countries, moved toward a new direction, which tended to accommodate pluralism and modern values. Muslim schools were forced to respond to social changes, otherwise society would have slowly ignored their presence.

Indonesian Muslim schools, with government assistance in managing their curricula, had responded positively to the demands of the Muslim society. While there were a number of Muslim schools that maintained their conservative curricula and traditional ways of teaching, the majority of Muslim schools changed.

\section{Conclusion}

The co-existence of secular curricula and Muslim school curricula indicated that Muslim schools played an important role in the country's education. From the political perspective, government policy to maintain the status quo of dual curricula implied three important points. First, the government acknowledged the importance of Muslim schools, as many Muslim parents continued to send their children to Muslim schools. Second, the government acknolewdged the contribution of Muslim schools. With the limited funding for education that government could provide, Muslim schools offered accessible education for economically disadvantaged families. Third, the mission of the government was to change Muslim schools into more modernized institutions in terms of contents, methods and facilities. The failure of the government to integrate the curricula of Muslim schools into the non-religious ones did not mean that the government failed to achieve its mission. On the contrary, the government was able to secure their agendas in promoting the changes in the Muslim schools, without changing the institutions.

While it was obvious that the government played an important role in changing the curricula and the standard of Muslim schools, the role of the Muslim communities were also significant to the changes. The positive responses from Muslim parents towards the changes in the curriculum indicated that they were in line with the expectation of society. It was true that some Muslim leaders decided not to follow the Government policy, and hence their instutions were not politically recognized, but this was not the majority. 


\section{References}

Daulay, H. P. (2001). Historisitas dan Eksistensi Pesantren, Sekolah dan Madrasah. Yogyakarta: Tiara Wacana.

Direktorat Jenderal Pembinaan Kelembagaan Agama Islam. (1999). Himpunan Peraturan Perundang-undangan tentang Pendidikan Nasional (Perguruan Agama Islam). Jakarta: Departemen Agama RI.

Djambek, S. (1976). Pelaksanaan Kurikulum Baru Madrasah Negeri dan Relevansinya dengan SKB 3 Menteri, in Proyek Penelitian Agama dan Kepercayaan terhadap Tuhan Yang Maha Esa, Sarana Pelaksanaan Kurikulum Baru Madrasah Negeri. Pp.38 - 69. Jakarta: Departemen Agama RI

Hasbullah. (1996). Sejarah Pendidikan Islam di Indonesia. Jakarta: LSIK.

Lee, K. H. (1995). Education and Politics in Indonesia 1945 - 1965. Kuala Lumpur: University of Malaya Press.

Maksum. (1999). Madrasah: Sejarah dan perkembangannya. Jakarta: Logos

Minister of Education and Culture. (1997). Fifty Years Development of Indonesian Education. Jakarta: Ministry of Education and Culture.

Pemerintah Republik Indonesia. (1990). Sistem Pendidikan Nasional (UURI Nomor 2 Tahun 1989) Beserta Peraturan Pelaksanaannya 1990. Jakarta: CV Eko Jaya.

Pohl, F. (2009). Islamic Education and the Public Sphere: Today's Pesantren in Indonesia. Berlin: Waxman.

Saleh, Abdurrahman. (1976). 'Pelaksanaan Kurikulum Baru Madrasah Negeri dan Relevansinya dengan SKB 3 Menteri,' in Proyek Penelitian Agama dan Kepercayaan terhadap Tuhan Yang Maha Esa, Sarana Pelaksanaan Kurikulum Baru Madrasah Negeri. Pp. 3-19. Jakarta: Departemen Agama RI.
Saridjo, M. (2010). Pendidikan Islam dari Masa ke Masa. Jakarta: Ngali Aksara.

Schubert, W. H. (1986). Curriculum: Perspective, paradigm and possibility. New York: Collier Macmillan.

Sirozi, M. (2004). Politik Kebijakan Pendidikan di Indonesia: Peran tokoh-tokoh Islam dalam Penyusunan UU No. 2/1989. Leiden: INIS.

Soedijarto. (1976). Tinjauan Komprehensif terhadap Kurikulum Tingkat Dasar, Menengah dan Madrasah Negeri, in Proyek Penelitian Agama dan Kepercayaan terhadap Tuhan Yang Maha Esa, Sarana Pelaksanaan Kurikulum Baru Madrasah Negeri, Pp. 20 - 37. Jakarta: Departemen Agama RI

Steenbrink, K. A. (1986). Pesantren, Madrasah, Sekolah: Pendidikan Islam dalam Kurun Modern. Jakarta: LP3ES.

Subhan, A. (2012). Lembaga Pendidikan Islam Indonesia Abad ke-20: Pergumulan antara modernisasi dan identitas. Jakarta: Kencana.

Syam, B. (1976). Realisasi Pelaksanaan Kurikulum Baru Madrasah Negeri, in Proyek Penelitian Agama dan Kepercayaan terhadap Tuhan Yang Maha Esa, Sarana Pelaksanaan Kurikulum Baru Madrasah Negeri. Pp. 3-19. Jakarta: Departemen Agama RI

Yunus, M. (1996). Sejarah Pendidikan Islam di Indonesia. Jakarta: Hidakarya Agung.

Zuhdi, M. (2005). The 1975 Three Minister Decree and the Modernization of Indonesian Islamic Schools. American Edcuational History Journal, 32, (1), pp. $36-43$. 